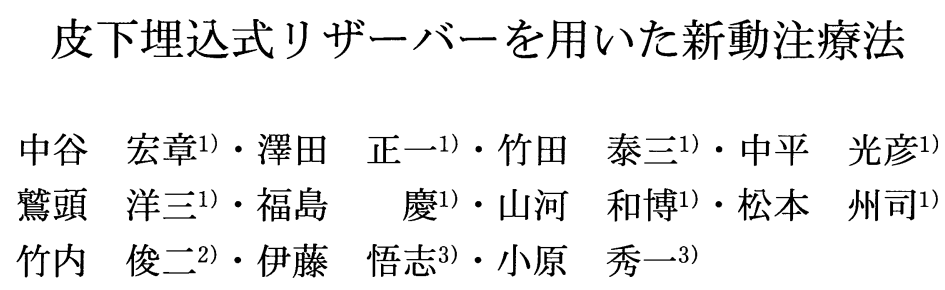

\title{
Intraarterial Infusion Therapy with an Implantable Reservoir System for Head and Neck Carcinomas
}

\begin{abstract}
Hiroaki Nakatani, Shoichi Sawada, Taizo Takeda, Mitsuhiko Nakahira, Yozo Washizu, Kei Fukushima, Kazuhiro Yamakawa, Shuji Matsumoto, Satoshi Ito and Shuichi Ohara
\end{abstract}

(Kochi Medical School)

Shunji Takeuchi

(Hata Municipal Hospital)

\begin{abstract}
We herein report the results of superselective intraarteial CDDP infusion therapy with an implantable reservoir system combined with radiotherapy for 10 patients with head and neck carcinomas. Two tumors originated from the external and middle ear, 4 from the maxillary sinus, 3 from the mesopharynx and 1 from the larynx. At first, we implanted an IVH reservoir system for administration of the neutralizing agent (sodium thiosulfate) to cisplatin (CDDP). After identification of the main arterial supply by the Seldinger technique and the first intraarterial infusion, we implanted an intraarterial reservoir system, using the facial, superficial temporal and superior thyroid arteries. CDDP infusion was performed from 3 to 7 times (average 4. 8). The complete and partial response rates were $50 \%$ and $40 \%$, respectively. Occlusion of the catheter and the artery occured in 2 and 1 patient, respectively. We conclude that the implantable resorvoir system for both CDDP and STS administration is an easy, low-invasive method for intraarterial infusion therapy.
\end{abstract}

Key words : head and neck carcinoma, superselective intraarteial infusion therapy, CDDP, implantable reservoir system

はじめに

頭頸部癌に対する超選択的動注治療はセルジンガー法 で行われるのが一般的であるが, 当科では複数回の抗癌 剤投与が必要な症例のためにリザーバーを用いた治療法 を開発した。リザーバー法は脳梗塞の危険性がなく，侵 襲性も少ない治療法である。そこで，今回リザーバ一療
法の手技と特徴について実例を示して報告する.

対 象
対象は 2002 年 4 月以降に当科を受診した頭頸部癌症例
中, リザーバー留置を行った 10 例である (表 1 ). 疾患
は外耳原発中耳進展例が 2 例, 上顎癌が 4 例, 中咽頭癌

1）高知大学聴平衡 - 嚥下機能統御学教室

2）幡多けんみん病院耳鼻咽喉科

3）高知大学腫瘍放射線医学教室 
表 1 詨象

\begin{tabular}{|c|c|c|c|c|c|c|c|}
\hline 症例 & 年齢 & 性 & 原発部位 & $\mathrm{T}$ & $\mathrm{N}$ & M & stage \\
\hline 1 & 68 & 男 & 外耳 - 中耳 & - & 0 & 0 & - \\
\hline $2^{*}$ & 69 & 女 & 外耳・中耳 & - & 0 & 0 & - \\
\hline 3 & 78 & 男 & 上顎 & 3 & 0 & 0 & III \\
\hline $4^{*}$ & 51 & 女 & 上顎 & 4 & 0 & 0 & IVA \\
\hline 5 & 50 & 女 & 上顎 & 4 & 0 & 0 & IVA \\
\hline 6 & 52 & 女 & 上顎 & 2 & 0 & 0 & II \\
\hline $7 *$ & 55 & 男 & 中咽頭側壁 & 4 & $2 \mathrm{~b}$ & 0 & IVA \\
\hline 8 & 70 & 男 & 中咽頭側壁 & 4 & 0 & 0 & IVA \\
\hline 9 & 59 & 男 & 中咽頭前壁 & 4 & 1 & 0 & IVA \\
\hline 10 & 76 & 男 & 喉頭 & 3 & 1 & 0 & III \\
\hline
\end{tabular}

*手術不能例

が 3 例，喉頭癌が 1 例であった。性別は男性 6 例，女性 4 例で, 年齢は 51 〜 78 歳 (平均 62.8 歳) であった. TNM分類のない外耳・中耳癌を除く8例の進行度はT2が 1 例，T3 が 2 例，T4 が 5 例，N0 が 5 例，N1 が 2 例, N2b が 1 例で, 遠隔転移例はなく, stage II が 1 例, stage III が 2 例，残る 5 例は stage IVA 例であった。なお，症例 2，4，7 は進行した原発部位あるいはリンパ節のため手 術による根治的摘出は困難と判断した症例であり, 症例
9 は 6 年前の下咽頭癌の治療により照射が行えない症例 であった。

\section{方法}

リザーバー留置（図1）は以下の手順を踏んで行った.

1）中心静脈用リザーバー留置

動注に用いるシスプラチン（CDDP）を中心静脈域で 中和するために行う。利き腕でない上肢近位部を駆血し て，尺側肘静脈の穿刺部位を決定。穿刺部位を局所麻酔 した後 $2 \sim 3 \mathrm{~mm}$ の小切開を行い, 静脈を露出. $18 \mathrm{G}$ 留 置針で目的静脈を穿刺する。留置針の外筒を通してガイ ドワイヤー（0.035 インチ，アングル型ラジフォーカス ガイドワイヤー：テルモ社）を上大静脈まで進め, さら にガイドワイヤーを通じて留置用のカテーテル（5 Fr ア ンスロン P-U カテーテル：東レ・メデイカル社）を上大 静脈まで插入する. 次いで, 穿刺部から $2 \sim 3 \mathrm{~cm}$ 末梢の 前腕正中部に皮下ポケットを作製する。穿刺部位加ら皮 下ポケットにカテーテルを誘導後, カテーテルを適切な 長さに切断し，ポート（P-U セルサイトポート：東レ・ メディカル社）に接続する。

2）セルジンガー法による動注
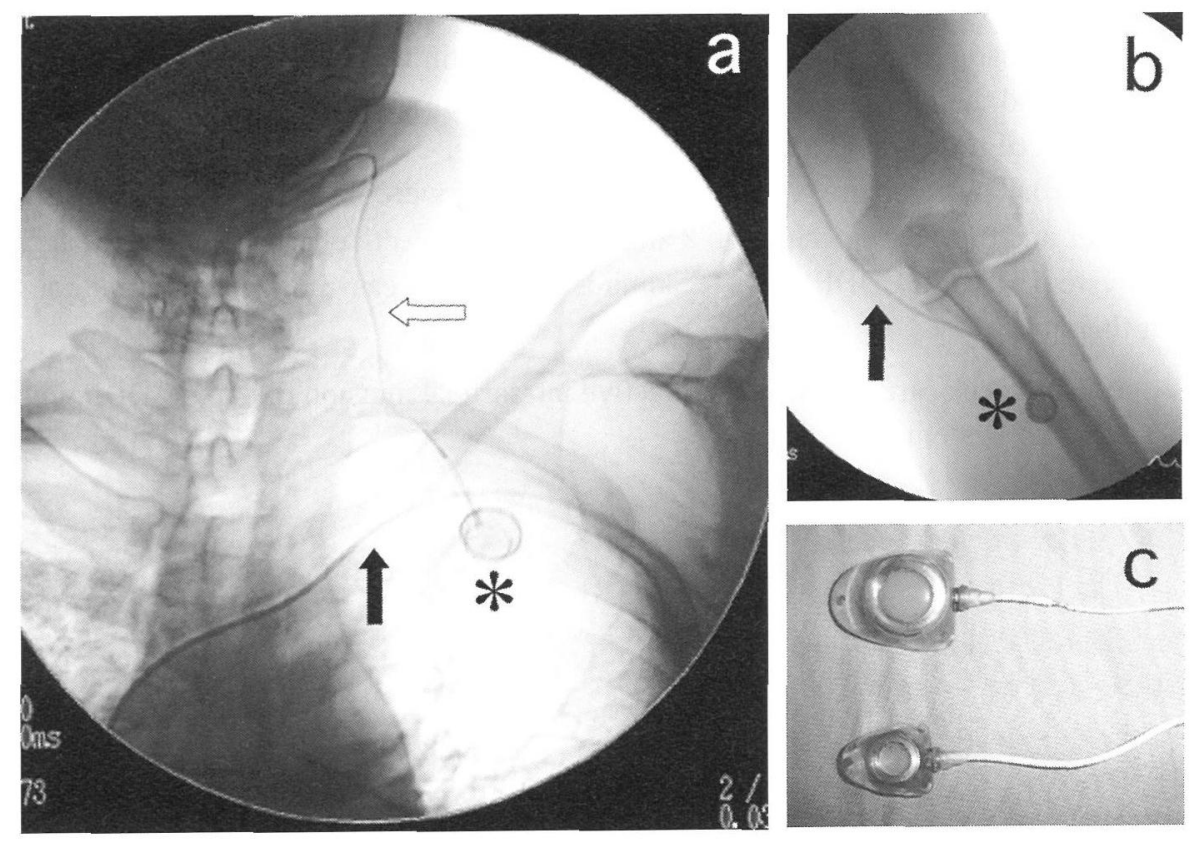

図1リザーバー

a : * ; 動注用ポート, $\Rightarrow$; 動注カテーテル, $\Rightarrow$; 中心静脈カテーテル

$\mathrm{b}: *$; 中心静脈用ポート, $\Rightarrow$; 中心静脈カテーテル

c：症例 3 亿用いた動注用ポート（上）と中心静脈用ポート 
腫瘍の栄養血管の確認と 1 回目の動注治療を目的とし て行う．頸動脈造影検査と同様の手技である．鼠径勒帯 のやや下方に局所麻酔を行った後, $2 \sim 3 \mathrm{~mm}$ の小切開 を加え，大腿動脈に穿刺針を挿入する．穿刺針の外筒内 にガイドワイヤーを挿入後, 外筒を抜去. 次いで, ガイ ドワイヤーを通じてイントロデュサー（5 Fr ラジフォー カスイントロデュサーIIH：テルモ社）を挿入する．イ ントロデュサーの内筒（ダイレーター）を抜去した後, 外筒（シース）内に $5 \mathrm{Fr}$ のガイディングカテーテル （Envoy：Cordis 社）を挿入し，外頸動脈まで進める．血 管造影により栄養動脈を同定後, ガイディングカテーテ ル内に動注用のマイクロカテーテル（Renegade fiber braided microcatheter：Boston Scientific 社）を挿入し，ガ イドワイヤー誘導下に腫瘍の栄養血管内まで進めて動注 を行う. CDDP 投与と同時に中心静脈用リザーバーから 中和剤であるチ才硫酸ナトリウム（STS）をモル比 200 倍量で 45 分，さらに同量を 6 時間追加投与する.

3）動注用リザーバー留置

セルジンガー法から $1 \sim 2$ 週後に, 確認された栄養血 管内にカテーテル留置を行う．栄盖血管以外の外頸動脈 分枝（浅側頭動脈など）からカテーテルを栄養血管に挿 入する. 動注用マイクロカテーテル挿入までの操作方法 はセルジンガー法と基本的には同じである．まず，外頸 動脈分枝を露出後に小切開を加え $4 \mathrm{Fr}$ のイントロデュ サーを挿入する.その後, ガイドワイヤー誘導下に $3.3 \mathrm{Fr}$ のアンスロン PU カテーテルを栄養血管に留置する. 浅 側頭動脈からカテーテルを挿入する場合には, 愛知県が んセンターで使用されている先端の弯曲したガイディン グカテーテル（4 Fr，Neck 型 M ：メディキット社）を用 いている. マイクロカテーテルの中枢側は頸部の皮下ト ンネルを経て鎖骨下に埋め込んだポートに接続する，以 後の動注はポートのセプタムに $22 \mathrm{G}$ のコレスニードル （ニプロ社）を刺入して行う.

CDDPの 1 回投与量は原則として $100 \mathrm{mg} / \mathrm{m}^{2}$ とし,放射 線照射と平行して $1 \sim 2$ 週に 1 回の投与を行った.なお， 治療中に口内炎以外で grade 2 以上の副作用をきたした 例はなかったが，動注後に食欲低下などの全身症状が比 較的強かった症例や高齢者, 計 3 例において $80 \mathrm{mg} / \mathrm{m}^{2}$ ま での減量を行った.

中心静脈リザーバー留置とセルジンガー法はすべて当 院放射線科医に依頼し, 動注リザーバー留置は放射線科 医と共同で行った。

\section{結 果}

10例の腫瘍栄養血管と動注用リザーバー留置に用いた 血管を表 2 に示す．症例 5 はまず顔面動脈からの挿入を 試みたが成功せず, 再度浅側頭動脈からリザーバー留置 を行った. 結局, 5 例が顔面動脈，4 例が浅側頭動脈，1 例が上甲状腺動脈から動注リザーバー留置を行った。な お, 症例 1 は浅側頭動脈之後頭動脈の両者から血流支配 を受けており, 留置カテーテルの先端は両血管分岐部よ りやや中枢側の外頸動脈に置いた。

治療結果を表 3 に示す．過去に下咽頭癌で $60 \mathrm{~Gy}$ の照 射を受けていた症例 9 を除く 9 例に $50 \sim 66 \mathrm{~Gy}$ の放射線 外照射を併用した. 動注回数は $3 \sim 7$ 回（平均 4.8 回） であったが, 症例 7 と 8 はカテーテル閉塞のため, 症例 10 は上甲状腺動脈の閉塞のため, 以後の動注治療は中止 となった. 残る 7 例は予定の動注が終了するまでカテー テルや血管の閉塞はみられなかった。 CDDP の総投与量 は $450 \sim 1225 \mathrm{mg}$ （平均 $734.8 \mathrm{mg}$ ）であった.

動注治療後に行った CT, MRI による原発部位の効果 判定では CR が 5 例 $(50 \%), \mathrm{PR}$ が 4 例 $(40 \%), \mathrm{NC}$ が 1 例 $(10 \%)$ であった. 治療方針として，上䪽癌例は CR 例でも上顎部分切除術を行った. 上顎部分切除術では機 能的にも整容的にも大きな問題を残さず，治療成績をよ り確実なものにできると考えたからである. その結果, 7 例に手術あるいは化学療法を追加した。ただし, 頸部リ ンパ節転移例はいずれも転移リンパ節も CR となり, 頸 部郭清術は行っていない. PR と NC 例中, 症例 2 と 4 は 手術不能, 症例 1 は手術拒否のため腫瘍の制御はできな かったが，残る 7 例においてはいまだ再発を認めていな い.

表 2 栄養血管とカテーテル挿入血管

\begin{tabular}{cccc}
\hline \hline 症例 & 原発部位 & 栄養血管 & カテーテル挿入血管 \\
\hline 1 & 外耳・中耳 & 浅側頭・後頭 & 顔面 \\
2 & 外耳・中耳 & 浅側頭 & 上甲状腺 \\
3 & 上顎 & 顎 & 顔面 \\
4 & 上顎 & 顎 & 顔面 \\
5 & 上顎 & 顎 & 顔面 $\rightarrow$ 浅側頭 \\
6 & 上顎 & 顎 & 浅側頭 \\
7 & 中咽頭側壁 & 顔面 & 顔面 \\
8 & 中咽頭側壁 & 顔面 & 顔面 \\
9 & 中咽頭前壁 & 舌 & 浅側頭 \\
10 & 喉頭 & 上甲状腺 & 浅側頭
\end{tabular}


表 3 治療内容

\begin{tabular}{cccccc}
\hline \hline 症例 & 動注回数 & CDDP 総量 $(\mathrm{mg})$ & 照射線量 $(\mathrm{Gy})$ & 原発部位の治療効果 & 追加治療 \\
\hline 1 & 5 & 748 & 60 & $\mathrm{PR}$ & 全身化学療法 \\
$2^{*}$ & 4 & 530 & 50 & $\mathrm{PR}$ & 全身化学療法 \\
3 & 5 & 690 & 50 & $\mathrm{CR}$ & 上顎部分切除 \\
$4^{*}$ & 6 & 850 & 50 & $\mathrm{NC}$ & TXT 動注 \\
5 & 6 & 910 & 50 & $\mathrm{PR}$ & 上顎部分切除 \\
6 & 4 & 560 & 50 & $\mathrm{CR}$ & 上䪽部分切除 \\
$7 *$ & 5 & 860 & 65.4 & $\mathrm{CR}$ & なし \\
8 & 3 & 450 & 65.4 & $\mathrm{CR}$ & なし \\
9 & 7 & 1225 & 0 & $\mathrm{PR}$ & 舌根部分切除 \\
10 & 3 & 525 & 66 & $\mathrm{CR}$ & なし \\
* 手術不能例 & & & & &
\end{tabular}

\section{症例}

症例 $3: 78$ 歳, 男性, 左上顎癌.

治療経過：他院耳鼻咽喉科で試験開洞術により扁平上 皮癌の診断を受け，平成 14 年 5 月 22 日当科紹介入院と なる。術前画像では左上顎洞に充満する腫瘍が後壁骨を 破壊する所見が得られ，T3N0M0， stage III と診断された (図 $2 \mathrm{a}$ ).

5 月 31 日, 左肘静脈からの中心静脈リザーバー留置後, セルジンガー法にて左外頸動脈造影検查を行い, 顎動脈 から血流支配があることを確認した後，第 1 回目の動注 施行. 6 月 21 日, 左顔面動脈から顎動脈の中硬膜動脈分 岐部よりやや末梢側でカテーテルを固定し，2 回目の動
注を施行（図 3)。7月 3 日から 8 月 6 日まで放射線治療 を行い, その間計 3 回リザーバーからの動注を追加した。 照射線量は 50 Gy で, CDDP の総投与量は $690 \mathrm{mg}$ であっ た。その結果，照射終了時には画像上 CR となったが (図 2 b)，組織学的な腫瘍残存の檢索も兼ねて，8月 22 日拡 大 Denker 手術を施行した。手術所見では肉眼上腫瘍は 確認されず，病理組織学的検索でもわずか 1 力所に変性 した細胞塊を認めるのみであった（大星・下里の病理組 織学的効果判定基準1) で grade III). 現在, 術後 10 力月を 経過しているが，再発徴候は認めていない。

症例 $5: 50$ 歳, 女性. 左上顎癌.

治療経過：平成 15 年 1 月 22 日初診. 左鼻腔内に充満
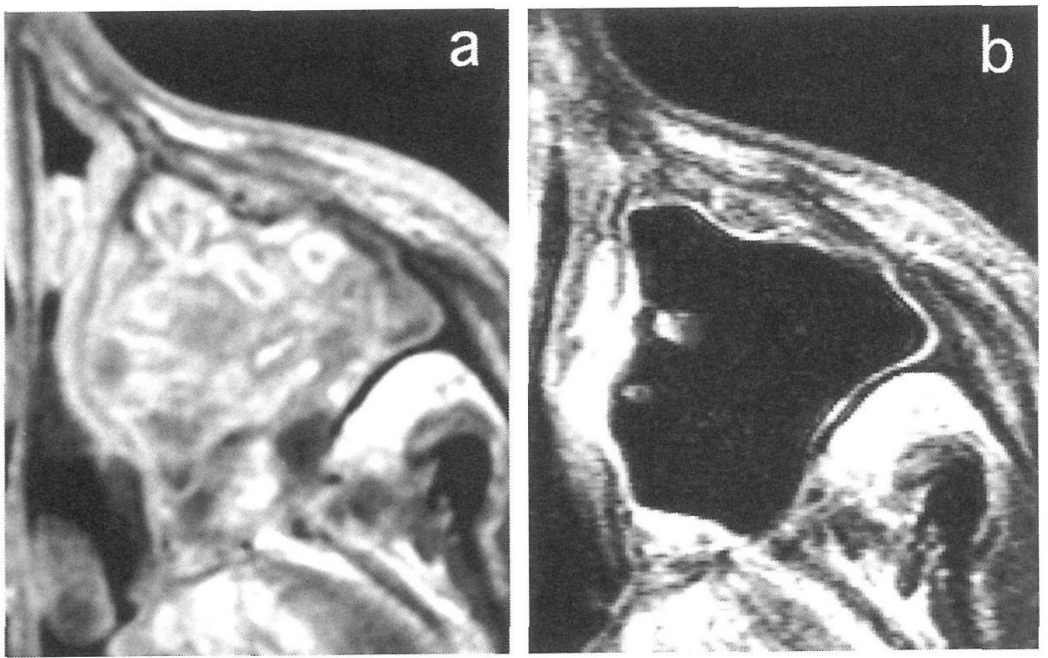

図 2 症例 3 の造影 MRI 所見（a：治療前，b：動注治療後）

治療前上顎洞内に充満していた腫瘍陰影が動注終了時には消失している. 


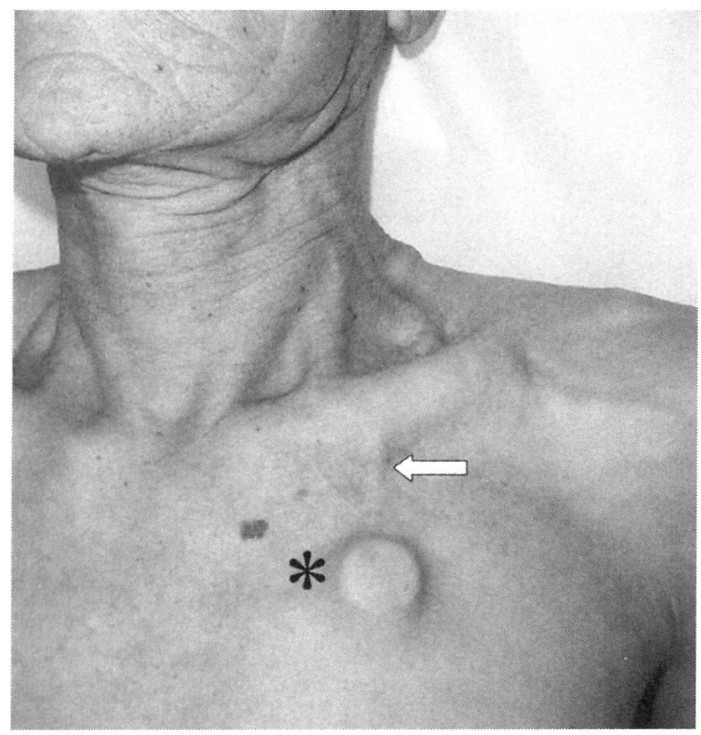

図 3 頸部外観 (*：動注用ポート， ：：動注カテーテル）

した腫瘍の組織検查結果から乳頭腫の診断を受けるも, 画像検查にて左上顎洞壁の広範な破壊像が確認され，精 查，治療目的にて 2 月 17 日入院． 2 月 18 日，左上顎洞 試験開洞術を行い，上顎洞内に存在する腫瘍組織から扁 平上皮癌の診断が得られた。 画像上, 腫瘍陰影は頭蓋底, 眼窩内に及び, T4NOM0, stage IVA と診断された (図 4 a).

2 月 25 日, 中心静脈リザーバー留置後, セルジンガー 法にて罰動脈分らの動注を施行. 3 月 11 日, 左顔面動脈 からのカテーテル挿入を試みるも，血管の弯曲が強く外
頸動脈末梢側へのカテーテル挿入ができず断念. 3 月 18 日，再度浅側頭動脈からのリザーバー留置を行った（図 5). 以後, リザーバーがら計 5 回, CDDP 総投与量 $910 \mathrm{mg}$ の動注を行った。また 2 月 27 日から 4 月 2 日まで, 計 $50 \mathrm{~Gy}$ の外照射を併用した。 その結果, 上顎洞内側から 節骨洞にかけて腫瘤陰影は認められるものの，上頢洞内 の陰影は著明に改善（図 4b)。鼻内および開洞部からの 2 回の生検結果も乳頭腫所見々変性の高度な癌組織の混 在する結果であったため, 残存腫瘍は主として乳頭腫と 考え，5月 8 日外側鼻切開術アプローチによる上顎部分 切除術を施行した。病理組織学的検索の結果は大星・下 里の判定基準 grade IIB であった.

症例 $7: 55$ 歳, 男性. 左中咽頭側壁癌.

治療経過：他院耳鼻咽喉科飞て左口蓋扁桃部の生検办 ら扁平上皮癌の診断を受け, 平成 14 年 10 月 21 日当科紹 介受診。治療前の画像診断で酒副咽頭間隙に大きく進展 した腫瘍と上内深頸領域の転移リンパ節がそれぞれ内側 と外側から内頸動脈に接し, 手術による完全摘出は困難 と判断した (図 $6 \mathrm{a}, \mathrm{b})$. 腫瘍の進展度は T4N2bM0, stage IVA と診断された。

10 月 28 日入院，11月 5 日中心静脈リザーバー留置施 行. 11 月 22 日セルジンガー法を施行し, 左顔面動脈分 枝の上行口蓋動脈と顔面動脈の小分枝から原発腫瘍と上 内深頸リンパ節両方に血流支配があることを確認後に動 注施行. 12 月 11 日, 顔面動脈の末梢側から上行口蓋動 脈分岐部より中枢側の顔面動脈内にカテーテルを留置
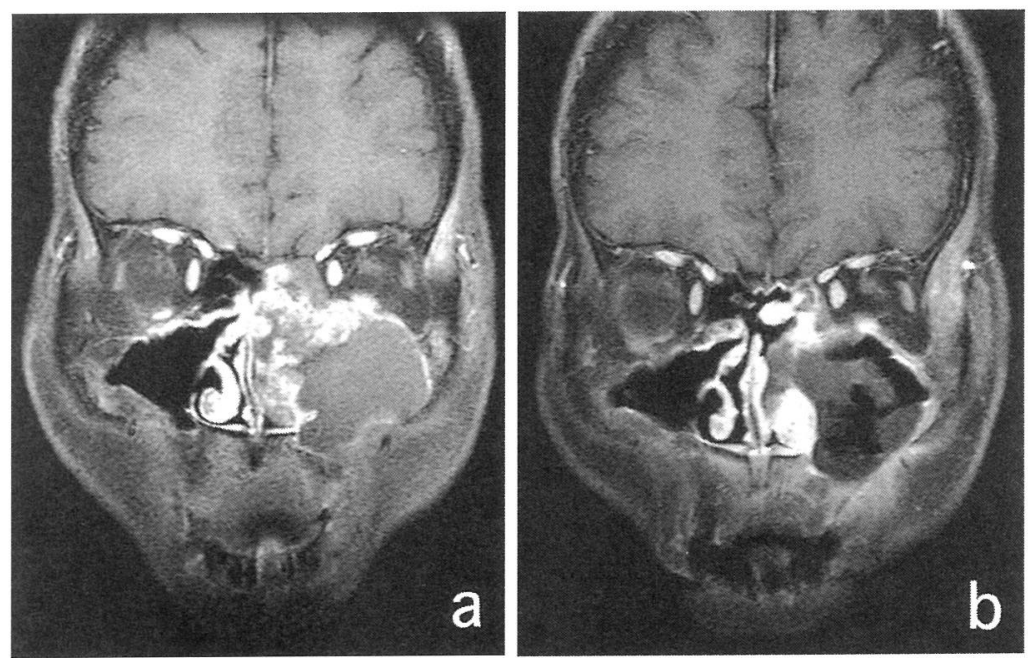

図 4 症例 5 の造影 MRI 所見 ( $\mathrm{a}$ : 治療前, b : 動注治療後)

治療前左上顎洞壁を広範に破壊していた腫瘍陰影が動注後には著明に縮小している. 

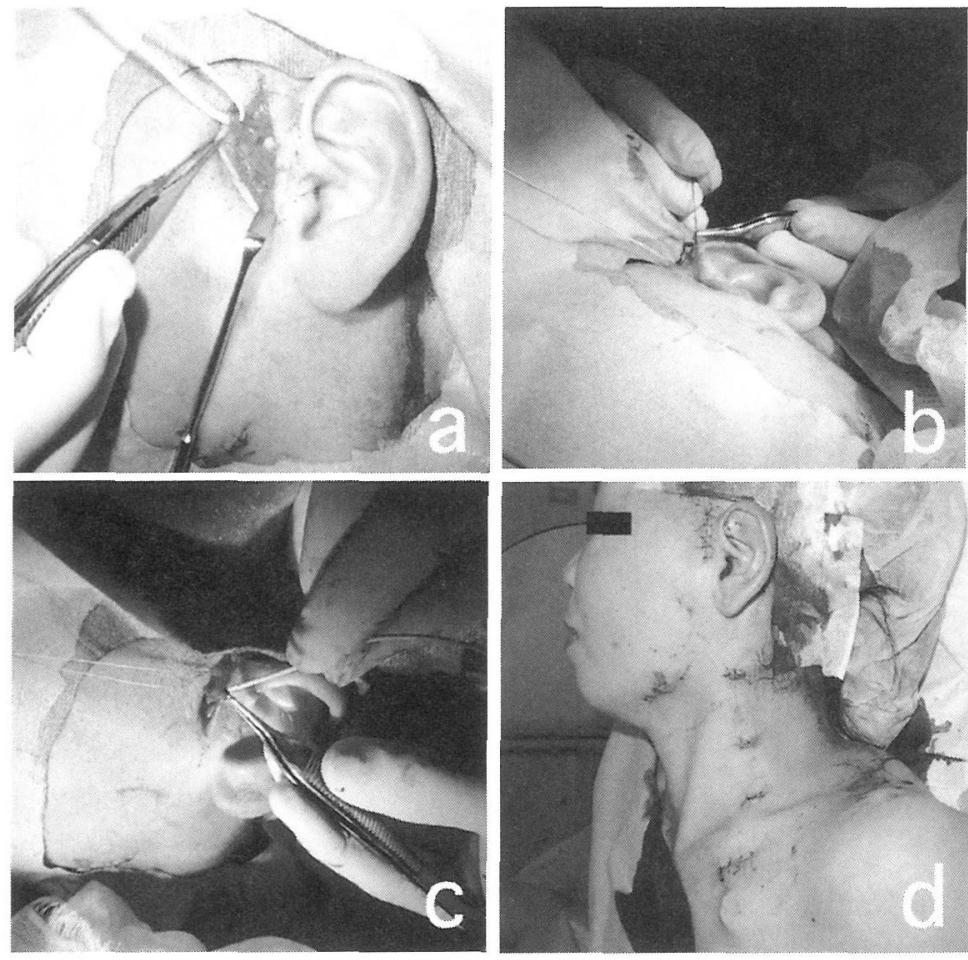

図 5 動注用リザーバー留置操作

$\mathrm{a}$ ：浅側頭動脈の露出, b : ガイドワイヤー挿入, $\mathrm{c}$ ：カテーテル挿入, $\mathrm{d} ：$ リザーバー埋め込み後
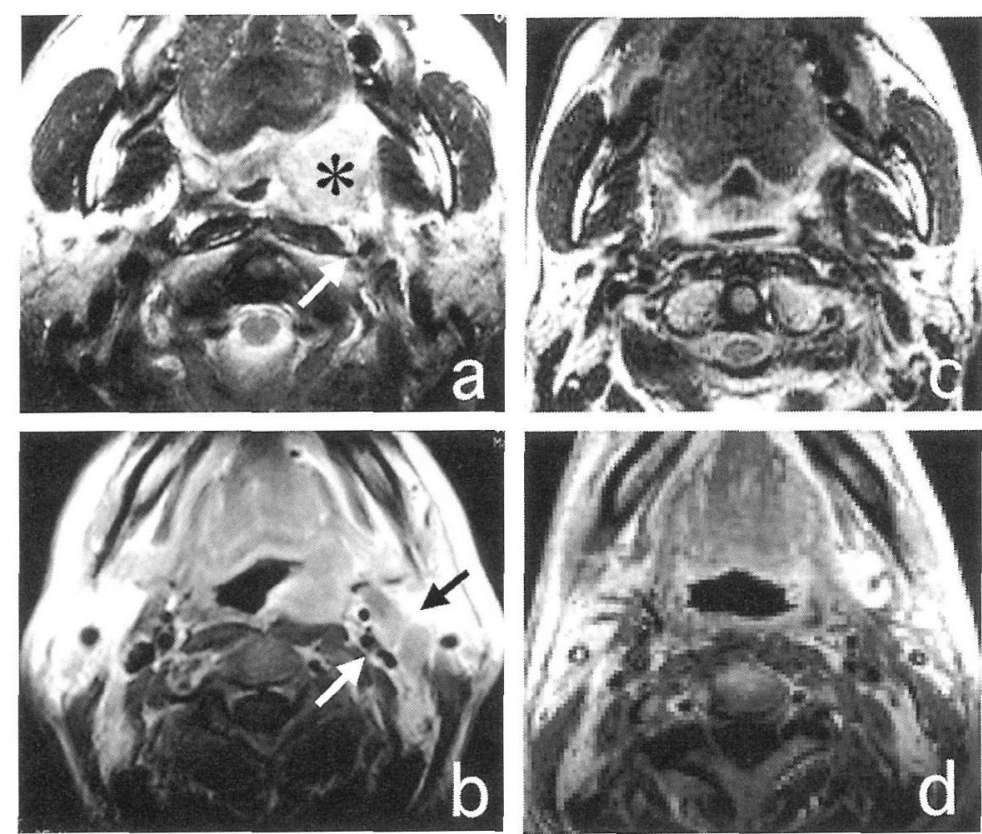

図 6 症例 9 の造影 MRI 所見（a，c：口蓋垂レベル，b，d：口蓋扁桃下極レベル） $\mathrm{a}$ : 腫瘍 $(*)$ は内側加ら内頸動脈 $(\Leftrightarrow)$ に接する

b : 上内深頸リンパ節 $(\rightarrow)$ が外側から内・外頸動脈, 内頸静脈 $(\hookrightarrow)$ に接する c, d : 治療後 
し，以後リザーバーから動注を行った。最終的に動注 5 回, CDDP 総投与量 $860 \mathrm{mg}$, 総照射線量 $65.4 \mathrm{~Gy}$ の治療 を行い，原発腫瘍と転移リンパ節は $\mathrm{CR}$ となった。治療 後 6 力月の現在, 再発徴候はない（図 $6 \mathrm{c}, \mathrm{d})$.

\section{考察}

近年, 諸施設で頭頸部癌に対する超選択的動注化学療 法が行われるようになってきた。 この治療法は決して新 しい治療法ではなく, 海外では 1982 年 2 , 本邦でも 1985 年には服部ら ${ }^{3)}$ の報告がある. しかしながら, その治療 効果が注目を浴びるようになったのは 1992 年 Robbins

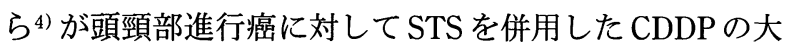
量投与により高い完治率を報告してからである.その後,

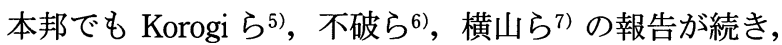
徐々に他施設でも行われるようになっている.

本治療法の特徵は，全身投与に比べはるかに高濃度の 抗癌剤を腫瘍内に取り込ませることができることと， CDDPを用いる場合にはSTSにより中和できるため全身 の副作用が少ないことにある. 副作用の軽減は CDDP 投 与量の増量と投与間隔の短縮をもたらし, 高濃度の抗癌 剂が長期間腫瘍組織内に維持できるため抗腫瘍効果が非 常に高い。しかも，頭頸部癌の原発部位は一つの外頸動 脈分枝から血流支配を受けることが多く，頭頸部癌にお ける有用性はきわめて高いと考えられる.

しかし超選択的動注治療にもいくつかの問題点があ り ${ }^{8)}$ 11), なかでも汎用されているセルジンガー法に伴 う脳梗塞はきわめて重篤な合併症として注意を要する. 諸家の報告8)11) では脳梗塞の頻度は $1 \%$ 前後とされてお り,まれな合併症とはいえない。さらに, 煩雑な操作, 治療に要する時間, 治療後の安静処置, 放射線科医に依 頼して血管造影室で行う必要があることなどを考える と，セルジンガー法による治療は簡単に行えるものでは なく，患者にとっても楽な治療とはいいがたい.

このような理由から，われわれは複数回の動注治療が 必要とされる症例には積極的にリザーバー法を行うこと にしている.リザーバー法は腫瘍の栄養血管以外の外頸 動脈分枝からカテーテルを挿入する方法で, 挿入したカ テーテルを留置, 固定して動注を行う．カテーテル操作 が外頸動脈系のみで行われるため脳梗塞の危険性がな く，操作に習熟すれば耳鼻咽喉科医のみで行うことも可 能な方法である.

ただし, 従来のリザーバー法はカテーテルを体外管理
するむのが多く316)，われわれが行っているような皮下に 埋め込む方法をとっている施設12)13) は少ない，体外管理 を行う場合には，カテーテルの閉塞防止のために持続注 入ポンプを携帯する必要があり，カテーテル挿入部から の感染防止のための処置を要するなど，管理が煩雑であ る.これに対し，皮下埋め込み法はポート内にヘパリン 液を注入しておけばカテーテル閉塞の危険性は少なく, 手間のかからない有用な方法である.

われわれのリザーバー法の特徴は中和剤を投与する中 心静脈カテーテルも皮下に埋め込むことにある．前腕皮 下への中心静脈カテーテルの埋め込みは比較的簡単で, 通常の穿刺法よりも安全である．両者を併用すると，以 後の動注操作は 2 つ皮下ポートに注射針を刺すだけで よく，通常の点滴治療と同程度の簡便性，低侵襲性で動 注治療が行える．CDDP を用いる場合，STS の中和効果 によって副作用の発現がきわめて低くなるため，短期入 院あるいは外来治療が行える可能性むあり，患者の受け るメリットは非常に大きいと考えている.

カテーテル挿入に用いられている外頸動脈分枝は頻用 されている浅側頭動脈 ${ }^{336) 13314)}$ 以外に，上甲状腺動脈 ${ }^{15)}$, 後頭動脈 16117$)$, 舌動脈 ${ }^{12)}$, 顔面動脈 ${ }^{12)}$ がある. このうち, 大村ら ${ }^{12)}$ の用いた方法は他の報告と異なり，腫瘍の栄養 動脈に直接カテーテルを挿入する方法である．大村ら ${ }^{12}$ は血流の遮断なくカテーテルを留置できた 3 例を報告し ているが，挿入部の出血のコントロール，血流の維持， 頸部深部での操作になることなど, 安定した成績を上げ にくい方法ではないかと思われる.

われわれも 5 例に顔面動脈を用いたが，亏ち 3 例は他 の血管への挿入のめ, 残る 2 例は顔面動脈中枢側の栄 養血管（上行口蓋動脈など）に動注を行うためで，全例 下顎骨下縁で血管を露出した。この部位では血管が表在 性に走行するため，カテーテル挿入操作は浅側頭動脈と 同様に難しくない．特に顔面動脈の中枢側に栄養血管が ある場合には,カテーテル留置操作も非常に簡単となる. ただし，今回カテーテルが閉塞した 2 例はこの方法を用 いた中咽頭側壁癌症例であった．末梢からのカテーテル 留置は血流に逆らう向きにカテーテルを挿入することに なるため，ヘパリン注入を頻回に行うなどの閉塞予防措 置が必要と考えられた．なお，閉塞したカテーテルは不 要となるため抜去するが，カテーテル挿入を行った皮切 部を再開放することにより簡単に摘出できる．血腫防止 のため, 指入部は結紮しておく. 
カテーテル留置の際には，選択性を意識して末梢をで 扱入しすぎると，カテーテルにより末梢側の血流が遮断 され，血管の閉塞を起こす危険性がある．カテーテル操 作や抗癌剤の投与は血管のスパスムや物理的・化学的 損傷によって血管内腔の狭小化を招きやすい行為であ る 699121213). このため, カテーテルを固定する際には, 血 流が十分に保たれていることを確認するとともに，重 炭酸ナトリウム使用による $\mathrm{pH}$ の調整やステロイドによ る内皮細胞障害の予防なども必ず行うべき処置と考え る7)10113)144.

皮下埋め込み法 ${ }^{12) 13)}$ による重篤なトラブルはこれまで 報告されていないが，不破ら ${ }^{6)}$ は体外式りザーバー施行 32 例中 4 例に栄養血管からのカテーテル脱落が生じたと 報告している．浅側頭動脈から Neck 型カテーテルを留 置する方法 6) では外頸動脈への掛かりが短いため脱落す る危険性がある. われわれは Neck 型を用いる場合でも， さらにこれにガイドワイヤーを通し, 小径のカテーテル を十分深く留置している. このため, 脱落例は 1 例もな かった．ただし，動注時には必ず血管造影や染色液を用 いた動注域の確認を行い，脱落のないことを確認した後 に動注を行うことが必要と思われる.

最後に，リザーバー法の適応は，1）動注治療の対象と なる進行癌例で，2）複数回の動注が必要な症例，3）力 テーテル挿入部近位に転移リンパ節がない症例，4）複数 の栄養血管をむたない症例と考えている. 3) の観点から は浅側頭動脈が最も用いやすい血管と考えられるが，何 らかの理由で浅側頭動脈が使用できない症例や前述した 中咽頭側壁癌などのような例では他の血管の使用も有効 と思われる。

\section{まとめ}

今回われわれは，セルジンガー法を用いた動注治療に 伴う脳梗塞の危険性を回避するために, 頭頸部癌 10 例に おいて動注および中心静脈カテーテルをともに皮下に埋 め込むリザーバー動注治療を施行した。 経過中 3 例に力 テーテルや血管の閉塞が生じたが，全例 3 回以上の動注 治療が施行できた。 CR 率は $50 \%$ ，奏効率は $90 \%$ であっ た。皮下埋め込み式りザーバー法は簡便，低侵襲で，し かも耳鼻咽喉科医にも可能な治療法である．動注治療を 考慮する施設においては是非とも習熟すべき治療法と考 える.

\section{参考文献}

1）大星章一, 下里幸雄, 板倉克明, 他：癌放射線療法の病理 〔I]癌組織の治癒過程の組織学的追跡（その 1). 医学のあ ゆみ $61: 618 \sim 625,1967$.

2) Sessions RB, Lehane DE, Smith RJH, et al. : Intra-arterial cisplatin treatment of adenoid cystic carcinoma. Arch Otolaryngol $108: 221 \sim 224,1982$.

3）服部孝雄, 平野忠則, 豊田 俊, 他 : 頭頸部腫瘍における 浅側頭動脈汃らの超選択的持続動注療法. 日本医放会誌 $45: 1056 \sim 1058,1985$.

4) Robbins KT, Storniolo AM, Kerber C, et al. : Rapid superselective high-dose cisplatin infusion for advanced head and neck malignancies. Head Neck $14: 364 \sim 371,1992$.

5) Korogi $Y$, Hirai $T$, Nishimura R, et al. : Superselective intraarterial infusion of cisplatin for squamous cell carcinoma of the mouth; preliminary clinical experience. AJR Am J Roentgenol $165: 1269 \sim 1272,1995$.

6）不破信和, 伊藤善之, 加藤恵理子, 他：頭頸部局所進行癌 に対する CBDCA 超選択的持続動注療法併用放射線治療. 頭頸部腫瘍 $22: 139 \sim 143,1996$.

7）横山純吉, 志賀清人, 西條 茂, 他：二経路投与法による 超選択的動注療法. 頭頸部腫瘍 $24: 335 \sim 343,1998$.

8）志賀清人, 舘田 勝, 横山純吉, 他 : 頭頸部扁平上皮癌に 対する超選択的動注療法の成績と合併症の検討. 頭頸部腫 瘍 $27: 9 \sim 16,2001$.

9）石田晃弘, 小池修治, 那須 隆, 他：超選択的二経路動注 化学療法における副作用と合併症についての検討. 頭頸部 腫瘍 $28: 243 \sim 247,2002$.

10）野本幸男, 鹿野真人, 渡邊 睦, 他：頭頸部癌に対する超 選択的 CDDP 動注療法の有害事象の検討. 頭頸部腫瘍 28 : $248 \sim 252,2002$.

11) Robbins KT, Kumar P, Wong FS, et al. : Targeted chemoradiation for advanced head and neck cancer; analysis of 213 patients. Head Neck $22: 687 \sim 693,2000$.

12) 大村正樹, 山本悦生, 过純, 他 : 頭頸部癌のリザーバー 動注療法. 頭頸部腫瘍 $19: 264 \sim 268,1993$.

13）竹内裕一, 長谷川賢作, 小山 司, 他 : 上顎癌症例におけ る皮下埋め込み式リザーバーの使用経験. 耳鼻 $46: 142 \sim$ 145, 2000.

14）横山純吉, 池田勝久, 小岩哲夫, 他：超選択的動注治療を 併用した鼻副鼻腔進行癌の治療. 日鼻誌 $39: 365 \sim 369$, 2000.

15）遠藤壮平, 木田亮紀, 龟谷隆一, 他：上咽頭癌頭蓋進展症 例. 日大医誌 $56: 289 \sim 292,1997$.

16）伊藤善之，不破信和，村元秀行，他：頭頸部腫瘍の局所動 注療法における二次治療としての後頭動脈からのアプロー チ. 日本医放会誌 $55: 1066 \sim 1067,1995$.

17）森 幸威, 折田洋造, 秋定 健, 他：頭頸部腫瘍に対する 後頭動脈チューブ留置術の検討. 耳鼻臨床 補 $96: 178$ 181, 1998.

原稿受付：平成15年 7 月 28 日 原稿採択 : 平成15年 9 月 24 日 急載 別刷請求先：中谷宏章 厂783-8505 南国市岡豊町小蓮 高知大学医学部聴平衡・曣下機能統御学教室 